\title{
Examination of Desalination Model Parameters on a Reverse Osmosis Desalination Simulation Model
}

\section{Bir Ters Ozmoz Tuzdan Arındırma Simülasyon Modeli Üzerinde Tuzdan Arındırma Modeli Parametrelerinin İncelenmesi}

\author{
Alper Burgaç ${ }^{1 *}$, Hakan Yavuz ${ }^{2}$
}

Revize / Revised: 27/09/2021

Kabul / Accepted: 29/09/2021

\begin{abstract}
The clean water and energy are both the most important needs of mankind. The increasing population and the necessity to meet the need for freshwater requirements make the desalination process a popular topic. The reverse osmosis is one of the most popular technique for desalination. The main advantages of the reverse osmosis over other desalination techniques are the lower energy consumption and the robustness to the salinity of feedwater. The ambient conditions are the key parameters affecting the efficiency of desalination process. On the other hand, the design parameters of a reverse osmosis desalination plant also play an important role in the process. In this paper, both ambient conditions and the design parameters are investigated. The contributions of the study are to determine variation the specific power consumption and related total power requirement of single stage reverse osmosis desalination plant model with the ambient conditions and design parameters. The effects of design parameters and ambient conditions for power requirements are given in the results section. The simulation studies are performed at constant production rate in order to see the effects of each parameter to product properties. The increase in seawater temperature for constant seawater salinity decreases the power consumption while increasing the salinity of final product. The results indicated that design parameters should be optimized according to the size of the designed system and salinity of feedwater. Also, a case study is performed for a point at Marmara Region, Turkey.
\end{abstract}

\section{Keywords- Reverse Osmosis, Desalination, Modelling}

\section{$\overline{\mathbf{O Z Z}}$}

Temiz su ve enerji insanlığın en önemli ihtiyaçlarındandır. Artan nüfus ve tatlı su ihtiyacının karşılanması ihtiyacı, tuzdan arındırma işlemini populer bir konu haline getirmektedir. Ters ozmoz, tuzdan arındırma için en populer tekniklerden biridir. Ters ozmozun diğer tuzdan arındırma tekniklerine göre temel avantajları, daha düşük enerji tüketimi ve besleme suyunun tuzluluğuna karşı gürbüzlüğüdür. Ortam koşulları, tuzdan arındırma işleminin verimliliğini etkileyen temel parametrelerdendir. Öte yandan, bir ters ozmoz prensibi ile tuzdan arındırma yapacak olan tesisinin tasarım parametreleri de bu süreçte önemli bir rol oynamaktadır. Bu çalışmada hem ortam koşulları hem de tasarım parametrelerinin etkileri incelenmiştir. Çalışmanın katkıları, tek aşamalı ters osmoz prensibi ile tuzdan arındırma yapan tesis modelinin özgül güç tüketimi ve ilgili toplam güç gereksiniminin ortam koşulları ve tasarım parametreleri ile değişimini belirlemektir. Güç gereksinimleri için tasarım parametrelerinin ve ortam koşullarının etkileri sonuç kısmında verilmiştir. Her parametrenin ürün özelliklerine etkisini görebilmek için

\footnotetext{
1*Sorumlu yazar iletişim: alperburgac@cu.edu.tr (https://orcid.org/0000-0002-0238-164X)

Faculty of Engineering, Mechanical Engineering Department, Çukurova University, Adana

2İletișim: hyavuz@cu.edu.tr (https://orcid.org/0000-0002-6166-0921)

Faculty of Engineering, Mechanical Engineering Department, Cukurova University, Adana
} 


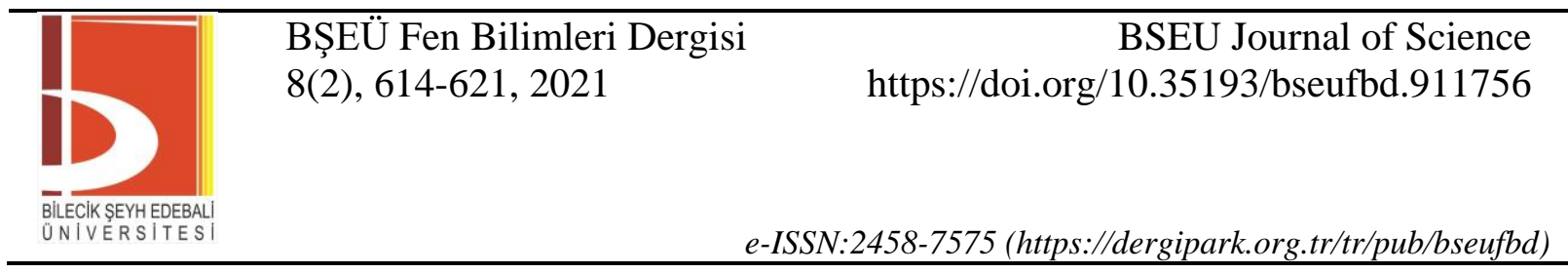

simülasyon çalışmaları sabit üretim hızında gerçekleştirilir. Sabit besleme suyu tuzluluğu için deniz suyu sıcaklığındaki artış, nihai ürünün tuzluluğunu artırırken güç tüketimini azaltır. Sonuçlar, tasarım parametrelerinin tasarlanacak sistemin boyutuna ve besleme suyunun tuzluluğuna göre optimize edilmesi gerektiğini göstermiş̧tir. Ayrıca, Türkiye'de Marmara Bölgesi'ndeki bir nokta için bir örnek durum çalışması yapılmıştır.

\section{Anahtar Kelimeler- Ters Ozmoz, Tuzdan Artndırma, Modelleme}

\section{INTRODUCTION}

The clean water and energy are among the most basic vital needs of human beings. The need for water is also increasing rapidly due to the increase in the world population and the increase in water demand in the industrial sector. The rate of increase in fresh water is expected to reach $50 \%$ by 2030 [1].

Mainly, the fresh water is supplied from lakes, rivers and also from underground water resources. It is known that only $0.8 \%$ of world's water reserve can be directly used as fresh water [2]. However, the increasing demand for fresh water leads researchers to find new freshwater resources. There are many traditional methods that have been applied so far to obtain clean water. The water reuse system [3], freshwater collector system, such as fog harvesting [4] and saltwater desalination system [5,6] are main freshwater production methods. The main freshwater production process from brackish water or seawater is named as desalination process. The desalination process can be defined as the removal of the salt and other impurities from seawater or brackish water. The freshwater production with desalination process is a growing field with the improvements of technological developments. The desalination process has many advantages, such as small footprint, modular design structure, allowing to use of the advanced control techniques and its ability of integration to renewable energy-based systems. In literature, there are some well-known desalination techniques. These techniques are classified into two main groups, namely as phase-change and thermal processes [7]. Amongst them, electrodialysis (ED), nano-filtration, multi-effect distillation (MED), multi-stage flash (MSF) techniques, and reverse osmosis (RO) are the most commonly used ones [8]. The contribution of the techniques to global freshwater production is given in Figure 1. The need for over energy demand and maintenance costs makes the reverse osmosis process much more attractive compared to other desalination methods [9]. It is mentioned [7] that both reverse osmosis and electrodialysis are used for brackish water; however, only reverse osmosis desalination can be used in salty seawater desalination.

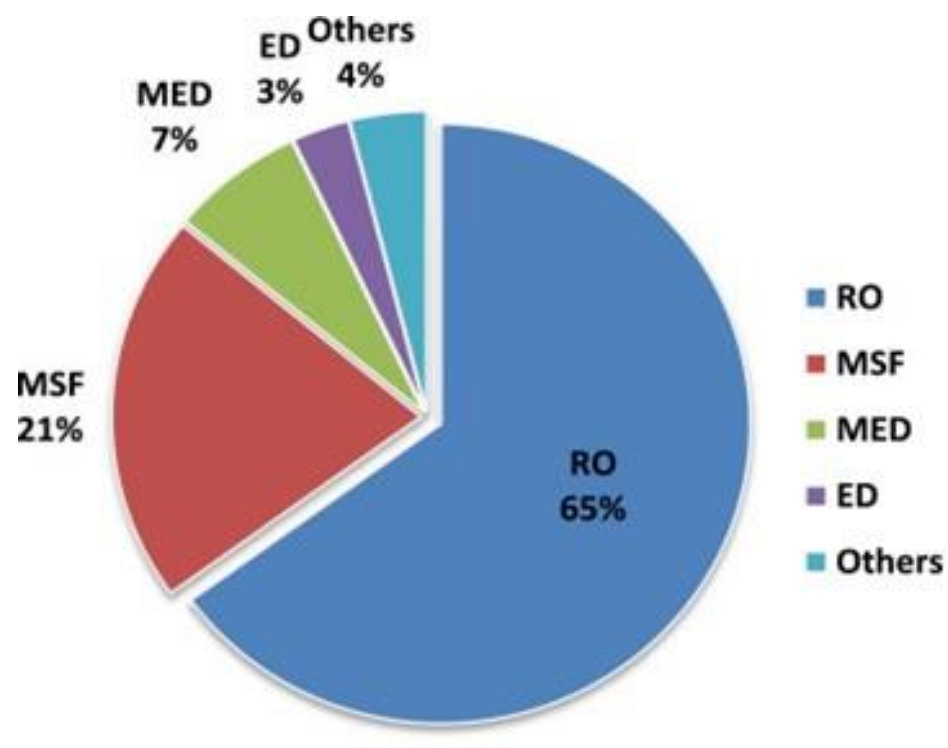

Figure 1. Contribution of desalination techniques [1]

There are some advantages of using reverse osmosis technique as desalination method. First of all, reverse osmosis technique has a wider production range from $1 \mathrm{~m}^{3} /$ day to $500000 \mathrm{~m}^{3} /$ day. Also, in reverse osmosis technique the salinity range of inlet water is relatively high. Besides, this technique can handle both brackish water and seawater as feed water source. In addition, the maintenance of the reverse osmosis plants is to be performed 
on a continuous basis [1]. Also, it is reported [10] that based on the installed capacity of plants; the reverse osmosis technique has mostly dominated the market of desalination process.

The electrical energy required for the operation of the facility constitutes a large part of the clean water production cost. This cost can be reduced by using renewable energy sources [1]. The use of alternative energy sources in water desalination, especially for reverse osmosis technique, is also an essential topic with many advantages. The solar, wind, wave, and geothermal energy sources are good alternative energy resources as they are eternal, abundant, and environmentally friendly [11-13].

The reverse osmosis process also become a standard technology in many fields, such as the wine industry, medical application, semiconductor manufacturing, drinking, and cooking [14]. Also, the reverse osmosis desalination system is investigated for daily water production needs [2]. The optimization of the design parameter of the reverse osmosis can lower the energy requirement [15]. It is reported that energy requirements can be optimized for desalination process with the use of renewable energy-based desalination systems as hybrid systems $[8]$.

In this study, a single stage desalination plant is modelled by using MATLAB/SIMULINK ${ }^{\mathrm{TM}}$ [16]. The desalination plant is operated using reverse osmosis technique. The relationship between salinity ratio of the feed water and the amount of energy required is previously represented [17]. In this study, other ambient parameters are investigated. This study examines the effects of the RO desalination parameters. The study is carried out in two cases. In the first case, the ambient parameters are kept same at the fixed values and the effects of design parameters are investigated. In the second case, the effect of sea water salinity and sea water temperature properties are investigated. Also, by using the investigation performed in these two cases, a local case study is performed. In following sections, the approach used in the development of the simulation model is explained in material and methods section, and the simulation results are presented. The aim of this study is examining the behaviour of the RO desalination plant for different ambient and design parameters. The results found in this study have been provided to lead the future studies to be done with modelling.

\section{MATERIALS AND METHODS}

The reverse osmosis process is based on using a high-pressure pump in order to pressurize the salt side of the process and force water through the reverse osmosis membrane. Almost all of the salt is left behind the membrane. However, pre-treatment should be performed before the water is fed to system in order to protect the membranes. The driving force of the reverse osmosis process is the pressure applied to saline water [17]. The simplified scheme of the RO desalination process is shown in Figure 2.

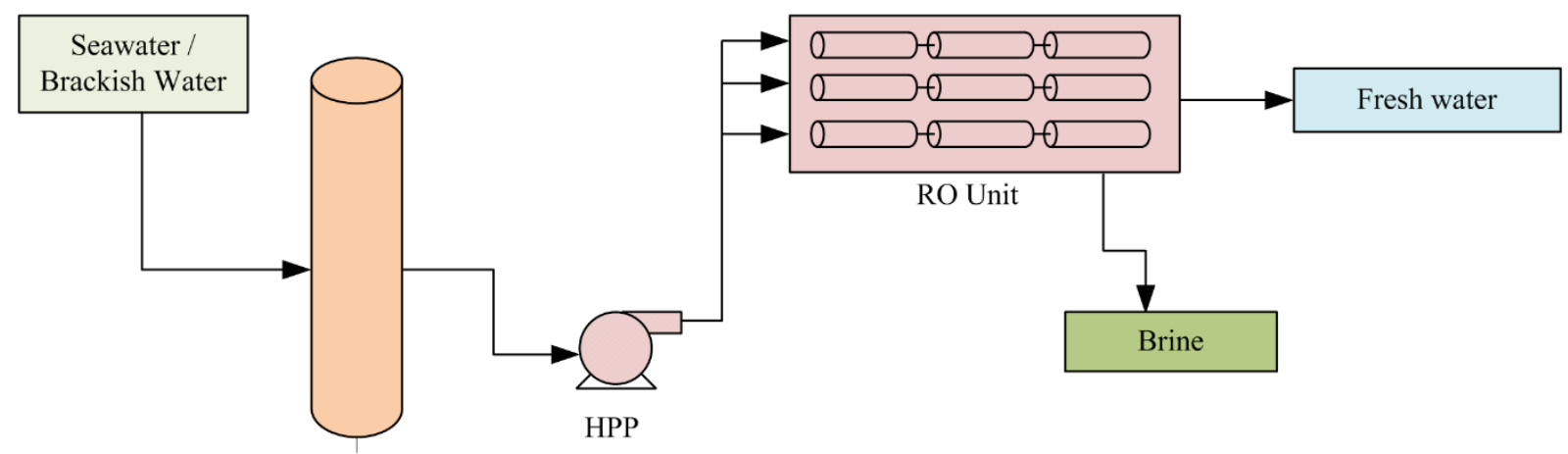

Pretreatment

Figure 2. Simplified scheme of RO desalination process

The block diagram of the single stage reverse osmosis model is given in Figure 3. The system is modelled by using MATLAB/SIMULINK ${ }^{\mathrm{TM}}$. The ambient temperature, seawater temperature, seawater salinity, membrane properties, feed flow rate, and the design parameters are fed to the Single Stage Reverse Osmosis (SSRO) plant as input. The block processes the input data and based on the mathematical model power consumption, permeate flow rate, the required feed pressure, the product salinity, the rejected brine mass flow rate, and the high-pressure pump are calculated. 


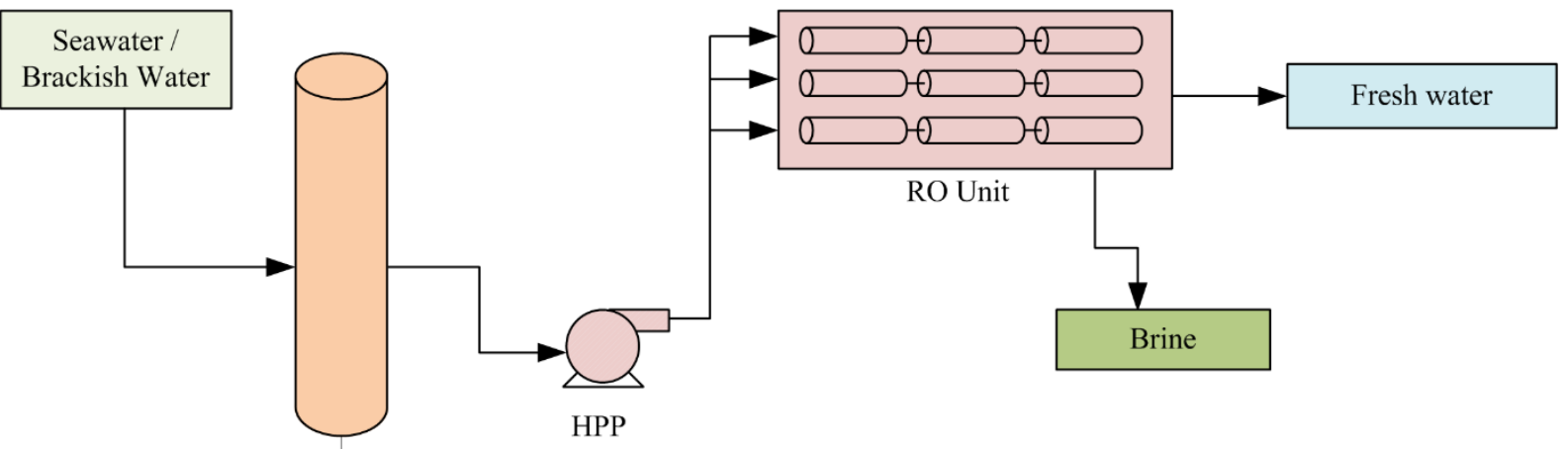

Pretreatment

Figure 3. Block diagram of single stage reverse osmosis desalination plant

The mathematical model for the proposed single stage reverse osmosis unit is developed using the process model presented as [17]:

The permeate mass flow rate $\left(M_{f}\right)$ based on recovery ratio $(R R)$ and distillate mass flow rate $\left(M_{d}\right)$ is

$M_{f}=M_{d} / R R$

The distillate product salt concentration $X_{d}$ :

$X_{d}=X_{f}(1-S R)$

where $X_{f}$ is the feed flow rate salt concentration, and $S R$ is the salt rejection percentage, and the rejected brine is found from:

$$
M_{b}=M_{f}-M_{d}
$$

the rejected salt concentration $X_{b}(\mathrm{ppm})$ is estimated by:

$$
X_{b}=\left(\left(M_{f} X_{f}\right)-\left(M_{d} X_{d}\right)\right) / M_{b}
$$

the average salt concentration $X_{a v}(\mathrm{ppm})$ is estimated as

$$
X_{a v}=\left(\left(M_{f} X_{f}\right)+\left(M_{b} X_{b}\right)\right) /\left(M_{f}+M_{b}\right)
$$

the temperature correction factor $T C F$ is found by the relation below, where $t_{\text {sea }}$ is the sea temperature

$$
T C F=\exp \quad\left(2700\left(\left(1 /\left(273+t_{\text {sea }}\right)\right)-(1 / 298)\right)\right)
$$

the membrane water permeability $k_{w}$ :

$$
k_{w}=\frac{\left(6.84\left(10^{-8}\right)\right)\left(\left(18.6865-\left(0.177 X_{b}\right)\right)\right.}{\left.\left(t_{\text {sea }}+273\right)\right)}
$$

the salt permeability $k_{\mathrm{s}}$ is

$$
k_{s}=(F F)(T C F)\left(4.72\left(10^{-7}\right)\right)\left(0.06201-\left(5.31\left(10^{-5}\right)\left(t_{\text {sea }}+273\right)\right)\right)
$$

where $F F$ is membrane fouling factor. The required power $(H P)$ for operation is:

$$
H P=\left(1000 M_{f} \Delta P\right) /\left(3600 \rho_{f} \eta_{p}\right)
$$

where $\Delta P$ is the net osmotic pressure across the membrane, $\rho_{f}$ is the feed flow rate density and $\eta_{p}$ is the driving pump efficiency. The specific power consumption $(S P C)$ is calculated as

$$
S P C=H P / M_{d}
$$




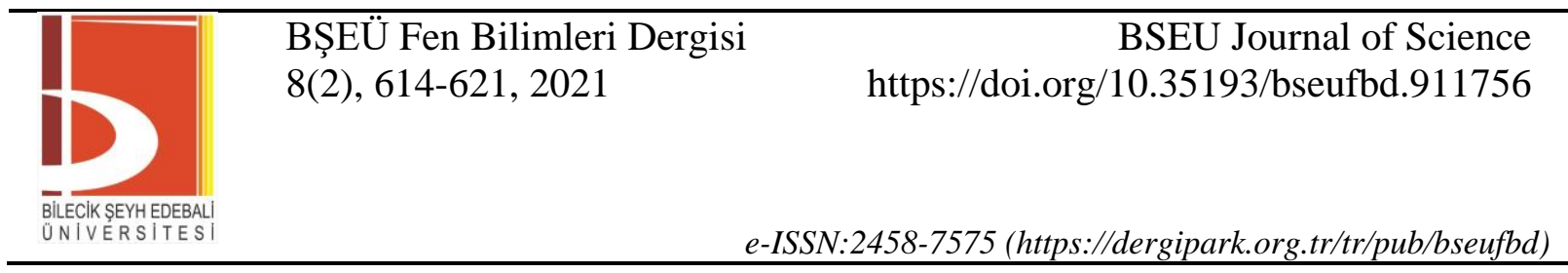

In this study, the simulation studies are performed based on the model for a SSRO plant which has $1000 \mathrm{~m}^{3} /$ day product rate. Both the effects of seawater parameters, and the design parameters are investigated in different stages. Also, a case study is performed. The local data is taken from Turkish State Meteorological Service and fed to modelled system. All the simulation results are provided in the next section.

\section{III.RESULTS AND DISCUSSION}

Energy consumption is a key factor affecting the cost of freshwater production which depends on both ambient conditions and design parameters. Also, final product properties play an important role in order to examine the quality of RO desalination. The effects of the ambient parameters on RO process are previously known task. However, the production rate also varies with the variation of these parameters [18]. In this study, for both two cases, the production rate is kept constant in order to clearly examine the effects of each parameter. In this part of the study, the simulations are performed for two different cases. In Table 1 the reverse osmosis desalination process parameters for proposed model are listed.

Table 1. Design parameters of single stage reverse osmosis desalination plant

\begin{tabular}{lc}
\hline Input Parameters & Output Parameters \\
\hline Ambient Temperature & \\
Sea Temperature & Total Power Consumption \\
Seawater Salinity & \\
Plant Productivity & Product Salinity \\
Number of pressure vessels / elements of vessels & \\
\hline
\end{tabular}

In first case, the design parameters of the plant are investigated. As the input parameter, the average seawater salinity is defined as $37000 \mathrm{ppm}$. The average ambient and seawater temperature is set to $25^{\circ} \mathrm{C}$. The system has recovery ratio of $30 \%$ and the fouling factor of 0.85 . The seawater membrane FTSW30HR-380 is used in the SSRO plant model. They are all kept constant. The effects of number of pressure vessels and the element number for each pressure vessels on power consumption and salinity are investigated. The results for a SSRO plant which is capable of production rate of $1000 \mathrm{~m} 3 /$ day for different design parameters are given in Table 2 . The effects of number of vessels and the elements for each vessel are also presented. It is seen that the power consumption decreases with using increasing number of vessels and increasing elements of number for each vessel. However, the product salinity increases with higher number of vessels. While designing the system, the optimization should be performed. The size of the plant, the unit cost of production, feedwater salinity are such parameters to be considered. It has been stated that the increased vessel number is used in large systems because it is more cost effective [19].

Table 2. The results for Case 1

\begin{tabular}{cccccc}
\hline $\begin{array}{c}\text { Size } \\
\left(\mathbf{m}^{\mathbf{3}} / \mathbf{d a y}\right)\end{array}$ & $\begin{array}{c}\text { Number of } \\
\text { vessels }\end{array}$ & $\begin{array}{c}\text { Number of } \\
\text { elements }\end{array}$ & $\begin{array}{c}\mathbf{S P C} \\
\left(\mathbf{k W h} / \mathbf{m}^{\mathbf{3}}\right)\end{array}$ & $\begin{array}{c}\text { Power Consumption } \\
(\mathbf{k W})\end{array}$ & $\begin{array}{c}\text { Product Salinity } \\
(\mathbf{p p m})\end{array}$ \\
\hline & 6 & & 4.667 & 194.5 & 426.5 \\
& 7 & 30 & 4.504 & 187.7 & 496.7 \\
& 8 & & 4.381 & 182.5 & 566.5 \\
\cline { 2 - 6 } 1000 & 6 & 4.504 & 187.7 & 496.7 \\
& 7 & 35 & 4.363 & 181.8 & 578.2 \\
& 8 & & 4.255 & 177.3 & 659.3 \\
\hline & 6 & & 4.339 & 180.8 & 594.4 \\
& 7 & 42 & 4.199 & 175.0 & 709.4 \\
& 8 & & 4.108 & 171.2 & 808.5 \\
\hline
\end{tabular}

The simulation results for different seawater temperature and seawater salinity values are listed in Table 3. It is shown from the results that the power consumption is increased with the increasing salinity of the feed water for same seawater temperature. Also, the increment in seawater temperature for constant seawater salinity decreases the power consumption. The reason for this decrease in energy requirement is that the increase in the 
feedwater temperature decreases the net driving pressure due to the increase in osmotic pressure [20]. However, the salinity of the produced desalinated water increases with the increasing seawater temperature.

Table 3. The results for Case2

\begin{tabular}{|c|c|c|c|c|c|}
\hline $\begin{array}{c}\text { Size } \\
\left(\mathrm{m}^{3} / \text { day }\right)\end{array}$ & $\begin{array}{c}\text { Seawater Temperature } \\
\left({ }^{\circ} \mathrm{C}\right)\end{array}$ & $\begin{array}{c}\text { Seawater Salinity } \\
(\text { ppm) }\end{array}$ & $\begin{array}{c}\text { SPC } \\
\left(\mathbf{k W h} / \mathbf{m}^{3}\right) \\
\end{array}$ & $\begin{array}{c}\text { Power Consumption } \\
(\mathbf{k W})\end{array}$ & $\begin{array}{c}\text { Product Salinity } \\
(\mathbf{p p m})\end{array}$ \\
\hline \multirow{9}{*}{1000} & & 30000 & 3.620 & 150.8 & 429.9 \\
\hline & 15 & 35000 & 4.179 & 174.1 & 501.5 \\
\hline & & 40000 & 4.761 & 198.4 & 573.1 \\
\hline & & 30000 & 3.524 & 146.8 & 498.6 \\
\hline & 20 & 35000 & 4.072 & 169.7 & 581.7 \\
\hline & & 40000 & 4.638 & 193.2 & 664.8 \\
\hline & & 30000 & 3.443 & 143.5 & 575.2 \\
\hline & 25 & 35000 & 3.980 & 165.8 & 671.0 \\
\hline & & 40000 & 4.534 & 188.9 & 766.9 \\
\hline
\end{tabular}

The results for Case 1 and Case 2 show the effect of both ambient parameters and design parameters to power consumption and produced water salinity. The results revealed in Case 1 and Case 2 both match the experimental results from previous studies [22,23].

Table 4. The temperature values for a location at Marmara Region.

\begin{tabular}{lllllllllllll}
\hline$\#$ & Jan & Feb & Mar & Apr & May & June & July & Aug & Sept & Oct & Nov & Dec \\
\hline $\mathrm{t}_{\text {air }}\left({ }^{\circ} \mathrm{C}\right)$ & 6.9 & 7.9 & 10 & 13.7 & 18.7 & 23.4 & 25.8 & 26 & 22.5 & 17.4 & 13.4 & 9.2 \\
$\mathrm{t}_{\text {sea }}\left({ }^{\circ} \mathrm{C}\right)$ & 10.5 & 10.1 & 10.8 & 13.8 & 19.2 & 23.4 & 25.1 & 26 & 24.6 & 20.5 & 17.4 & 14.2 \\
\hline
\end{tabular}

Also, a case study is performed for a location at Marmara Region. In case of a drinking water shortage in this region in the coming years, a study was conducted using a simulation model. The annual average data of air temperature and sea water temperature data obtained from Turkish State Meteorological Service were obtained. The variations of the air temperature $\left(t_{\text {air }}\right)$ and the seawater temperature $\left(t_{\text {sea }}\right)$ by months are presented in Table 4 .

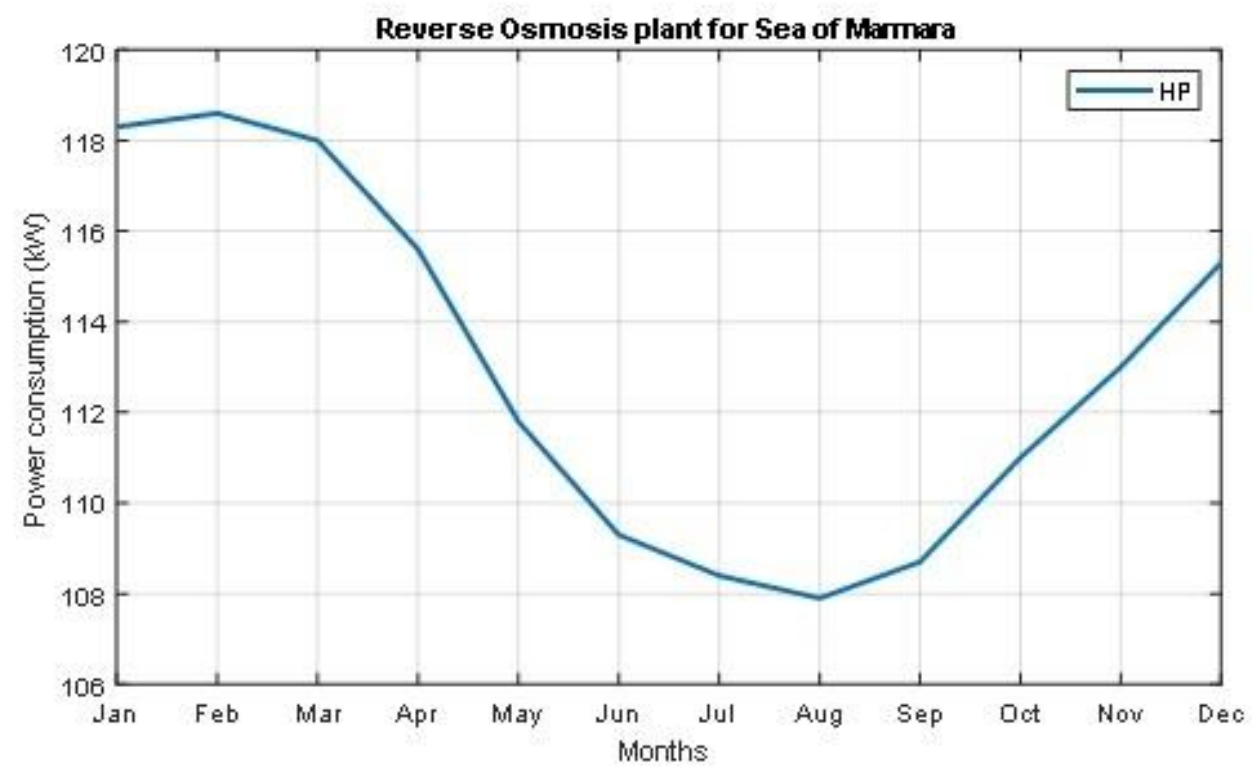

Figure 4. Power consumption of RO desalination plant 
The average seawater salinity of Sea of Marmara is taken $22000 \mathrm{ppm}$ in average. The design parameters are kept constant in order to see the ambient effects on the production and the power consumption. The productivity rate is fixed at $1000 \mathrm{~m}^{3} /$ day. It can be clearly seen from the Figure 4 that the power consumption decreases while the ambient temperatures increase.

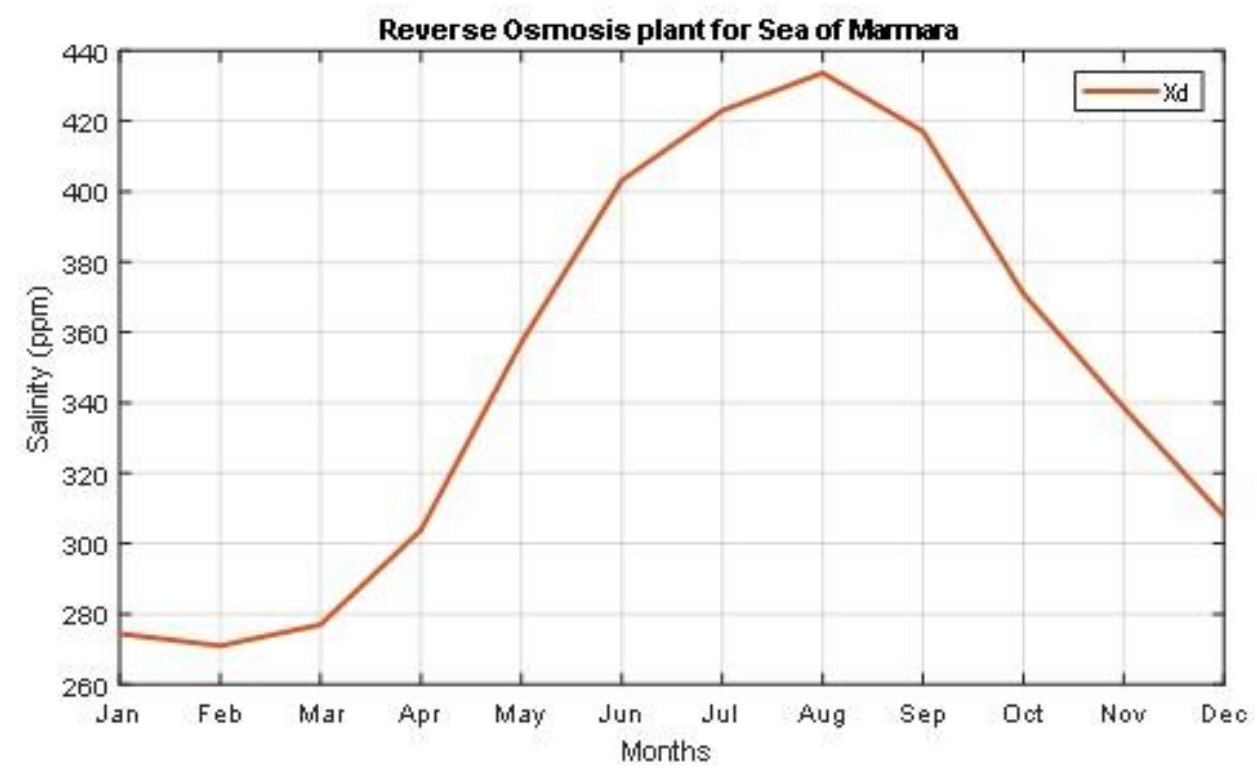

Figure 5. Salinity of product over year

The design parameters are kept constant in order to observe the effects of the ambient conditions on salinity as well as power consumption. The salinity variation of the final product is given in the Figure 5. The salinity of the purified water increases while the temperature of ambient and the seawater increases.

\section{CONCLUSION}

In this study, a desalination plant based on SSRO principle is modelled. The effect of basic design parameters and the ambient conditions are investigated. The relationship between salinity ratio of the feed water and the amount of energy required is previously represented [17]. In this study, other ambient parameters are investigated. It is shown from the results that the different conditions and design parameters effects the power consumption and the produced water salinity directly. The power consumption observed decreases with the increasing vessel number. However, the product salinity increases with increasing number of vessel and element numbers. As a conclusion of this case, the higher the number of vessel and element will be, the bigger size of reverse osmosis plants. For the other case, it is shown that the quality of permeate is highly dependent on the seawater salinity and the temperature. This result complies with the studies presented by [20,21]. In addition, as it can be seen from the results, it is important to perform the optimization to desalination plants in order to produce high quality of permeate in areas with water shortage.

The parameter optimization studies and control applications for reverse osmosis plants should be far more beneficial for a reverse osmosis desalination plant. Also, as a future work, renewable energy-based desalination system,such as wind, solar or wave combined systems, can be more feasible not only for decreasing the energy requirement for desalination but also for fresh water production at off-grid locations.

\section{REFERENCES}

[1] Mito, M., Ma, X., Albuflasa, H., \& Davies, P. A. (2019). Reverse osmosis (RO) membrane desalination driven by wind and solar photovoltaic (PV) energy: State of the art and challenges for large-scale implementation. Renewable and Sustainable Energy Reviews, 112, 669-685. 
[2] Mansour, T. M., Ismail, T. M., Ramzy, K., \& El-Salam, M. A. (2020). Energy recovery system in small reverse osmosis desalination plant: Experimental and theoretical investigations. Alexandria Engineering Journal, 59(5), 3741-3753.

[3] Dixon, A., Butler, D., \& Fewkes, A. (1999). Water saving potential of domestic water reuse systems using greywater and rainwater in combination. Water Science and Technology, 39(5), 25-32.

[4] Batisha, A. F. (2015). Feasibility and sustainability of fog harvesting. Sustainability of Water Quality and Ecology, 6, 1-10.

[5] Lin, S., Zhao, H., Zhu, L., He, T., Chen, S., Gao, C., \& Zhang, L. (2021). Seawater desalination technology and engineering in China: A review. Desalination, 498, 114728.

[6] Greenlee, F. L., Lawler. F. D., Freeman, B. D, Marrot, B., \& Moulin, P. (2009). Reverse osmosis desalination: Water sources, technology, and today's challenges. Water Research, 43(9), 2317-2348.

[7] Kalogirou, S. A. (2005). Seawater desalination using renewable energy sources. Progress in Energy and Combustion Science, 31(3), 242-281.

[8] Clemente, D., Rosa-Santos, P., \& Taveira-Pinto, F. (2021). On the potential synergies and applications of wave energy converters: A review. Renewable and Sustainable Energy Reviews, 135, 110162.

[9] Nassrullaha, H., Anisa, S. F., Hashaikeha, R., \& Hilal, N. (2020). Energy for desalination: A state-of-the-art review. Desalination, 491, 114569.

[10] Amy, G., Ghaffour, N., Li, Z., Francis, L., Linares, R. V., Missimer, T., \& Lattemann, S. (2017). Membranebased seawater desalination: Present and future prospects. Desalination, 401, 16-21.

[11] Borge-Diez, D., García-Moya, F. J., Cabrera-Santana, P., \& Rosales-Asensio, E. (2020). Feasibility analysis of wind and solar powered desalination plants: An application to islands. Science of The Total Environment, $764,142878$.

[12] Charrouf, O., Betka, A., Abdeddaim, S., \& Ghamri, A. (2020). Artificial Neural Network power manager for hybrid PV-wind desalination system. Mathematics and Computers in Simulation, 167, 443-460.

[13] Leijon, J., Salar, D., Engström, J., Leijon, M., \& Boström, C. (2020). Variable renewable energy sources for powering reverse osmosis desalination, with a case study of wave powered desalination for Kilifi, Kenya. Desalination, 494, 114669.

[14] Gambier, A., \& Badreddin, E. (2009). Control of Small Reverse Osmosis Desalination Plants with Feed Water Bypass. $18^{\text {th }}$ IEEE International Conference on Control Applications. 13-14 July, Saint Petersburg, 800-805.

[15] Oh, H. J., Hwang, T. M., \& Lee, S. (2009). A simplified simulation model of RO systems for seawater desalination. Desalination, 238, 128-139.

[16] MATLAB version 9a. (2009). Massachusetts: The MathWorks Inc 3 Apple Hill Drive.

[17] Nafey, A. S., \& Sharaf, M. A. (2010). Combined solar organic Rankine cycle with reverse osmosis desalination process: Energy, exergy, and cost evaluations. Renewable Energy, 35, 2571-2590.

[18] Sassi, K. M., \& Mujtaba, I. M. (2012). Effective design of reverse osmosis-based desalination process considering wide range of salinity and seawater temperature. Desalination, 306, 8-16.

[19] Altaee, A. (2013). Theoretical study on feed water designs to reverse osmosis pressure vessel. Desalination, $326,1-9$.

[20] Koutsou, C. P., Kritikos, E., Karabelas, A. J., \& Kostoglou, M. (2020). Analysis of temperature effects on the specific energy consumption in reverse osmosis desalination processes. Desalination, 476, 114213.

[21] Akgul, D., Çakmakcı, M., Kayaalp, N., \& Koyuncu, I. (2008). Cost analysis of seawater desalination with reverse osmosis in Turkey. Desalination, 220(1-3), 123-131.

[22] Elsayed, M., Refaey, H. A., Abdellatif, O. E., Sakr, R. Y., \& Afify, R. I., (2018). Experimental investigation on the performance of a small reverse osmosis unit. Journal of the Brazilian Society of Mechanical Sciences and Engineering, 40, 218.

[23] Sarai Atab, M., Smallbone, A. J., \& Roskilly, A. P., (2016). An operational and economic study of a reverse osmosis desalination system for potable water and land irrigation. Desalination, 397, 174-184. 